\title{
INSRR Gene
}

National Cancer Institute

\section{Source}

National Cancer Institute. INSRR Gene. NCI Thesaurus. Code C24517.

This gene is thought to play a role in insulin regulation; however, the exact function is not known. 